\title{
Stimulation by Triiodothyronine of the In Vitro Uptake of Sugars by Rat Thymocytes
}

\author{
JoSEPH SEgal and SidNEY H. INGBAR, Thorndike Laboratory of Harvard Medical \\ School and the Department of Medicine, Beth Israel Hospital, \\ Boston, Massachusetts 02215
}

\begin{abstract}
A B S T RACT Studies were conducted to ascertain the in vitro effect of $3,5,3^{\prime}$-triiodothyronine $\left(\mathrm{T}_{3}\right)$ on the accumulation of the glucose analogue, 2-deoxyglucose (2-DG), by thymocytes freshly isolated from weanling rats. At a concentration of $1 \mu \mathrm{M}, \mathrm{T}_{3}$ stimulated the 15min uptake of ${ }^{3} \mathrm{H}-2-\mathrm{DG}$ after cells had been exposed to $T_{3}$ for only $30 \mathrm{~min}$. Significant stimulation of 2-DG accumulation was produced by $1 \mathrm{nM} \mathrm{T}_{3}$, with increasing stimulation at doses ranging up to $10 \mu \mathrm{M}$. $\mathrm{T}_{3}$ did not alter the fraction of accumulated 2-DG that was phosphorylated, and kinetic studies indicated that its effect was associated with a significant increase in the apparent $V_{\max }$ of 2-DG accumulation, but not the apparent $K_{\mathrm{m}} \cdot \mathrm{T}_{3}$ also enhanced the accumulation by thymocytes of the nonmetabolized glucose analogue, 3-O-methylglucose (3-O-MG), an effect that was evidently the result of an increase in 3-O-MG transport into the cell, because it was seen in cells incubated with ${ }^{3} \mathrm{H}-3-\mathrm{O}-\mathrm{MG}$ for only $30 \mathrm{~s}$. The proportionate increase in 2-DG accumulation produced by $\mathrm{T}_{3}$ was not altered by preincubating cells with concentrations of puromycin or cycloheximide sufficient to reduce $\left[{ }^{3} \mathrm{H}\right]-$ leucine incorporation by $95 \%$, and $\mathrm{T}_{3}$ over a period of $>2 \mathrm{~h}$ had no effect on $\left[{ }^{3} \mathrm{H}\right]$ leucine incorporation itself.

These results indicate that $\mathrm{T}_{3}$ stimulates the uptake of sugars in rat thymocytes in vitro by an effect on their inward transport. The promptness of the effect and its failure to be inhibited during profound inhibition of protein synthesis further indicate that this effect of $T_{3}$ is not mediated through a nuclear-dependent mechanism. Rather, the properties of this response, and of the increases in amino acid and 2-DG accumulation produced by $T_{3}$ in other tissue preparations, strongly suggest that these effects of $T_{3}$ are mediated at the level of cell membrane.
\end{abstract}

Received for publication 4 August 1978 and in revised form 15 November 1978.

\section{INTRODUCTION}

Recent years have seen a great growth of interest in the primary mechanism of action of the thyroid hormones. The voluminous data that have resulted strongly suggest that the thyroid hormones exert a primary effect at the level of the cell nucleus (1-5), and perhaps the mitochondrion as well (6-8). In addition, evidence has grown that the thyroid hormones may also exert a direct effect that the level of the cell membrane. 3,5,3'-Triiodothyronine $\left(\mathrm{T}_{3}\right)^{1}$ and other thyroactive materials have, for example, been shown to stimulate the in vitro accumulation of certain amino acids by chick embryo cartilage and rat thymocytes $(9-11)$, and, in the case of the rat thymocyte, this effect has been found after in vivo administration of $\mathrm{T}_{3}(12)$. In addition, in cultured chick embryo myocardial cells, $T_{3}$ enhances cellular uptake of the glucose analogue, 2-deoxyD-glucose (2-DG) $(13,14)$. All of these effects on substrate accumulation occur promptly and are independent of ongoing protein synthesis. In the present studies we demonstrate that the effect of $T_{3}$ on cellular 2-DG uptake is not limited to the chick myocardium, but appears to be more general, because it occurs as well in the rat thymocyte, where it is also prompt and independent of new protein synthesis, and results from enhancement of the transport of 2-DG into the cell, rather than in increase in its phosphorylation.

\section{METHODS}

Thymocyte suspensions. Rats of the CD strain, ranging in age between 25 and $27 \mathrm{~d}$, were purchased from Charles River Breeding Laboratories (Wilmington, Mass.) and were maintained for a maximum of $\mathbf{6} \mathrm{d}$ before study on a diet of Purina laboratory chow (Ralston Purina Co., St. Louis, Mo.).

${ }^{1}$ Abbreviations used in this paper: 2-DG, 2-deoxy-Dglucose; 3-O-MG, 3,O-methyl-D-glucose; $\mathrm{T}_{3}, 3,5,3^{\prime}$-triiodothyronine. 
Thymocytes were then harvested according to the method described by Goldfine and co-workers (11). Briefly, animals were killed by cervical dislocation, thymus glands were quickly removed and washed in ice-cold Krebs-Ringer $25 \mathrm{mM}$ Tris buffer, $\mathrm{pH}$ 7.5. Tissues were then gently teased, and the thymocytes therey liberated were filtered through nylon mesh and centrifuged at $800 \mathrm{~g}$ for $5 \mathrm{~min}$. The supernate was decanted and the cell pellet was resuspended in buffer. Thymocytes were counted in a hemocytometer and additional buffer was added to yield a final thymocyte concentration of 45 $\times 10^{6}$ cells $/ \mathrm{ml} .3 \mathrm{ml}$ of the cold suspension was pipetted into siliconized Erlenmeyer flasks, and these were incubated during a $30-\mathrm{min}$ equilibration period at $37^{\circ} \mathrm{C}$ in room air. Thereafter, preincubation or incubation periods, as indicated below, were initiated.

${ }^{3} \mathrm{H}-2-D G$ uptake. Either at the beginning of incubation or more commonly, after preincubation of cell suspensions with various agents, ${ }^{3} \mathrm{H}-2-\mathrm{DG}(8.26 \mathrm{Ci} / \mathrm{mmol} \mathrm{sp} \text { act })^{2}$ was added to the medium to a final concentration of $3 \mu \mathrm{Ci} / \mathrm{ml}(0.36 \mu \mathrm{M})$. After specified periods, $200-\mu \mathrm{l}$ aliquots were removed, pipetted into microtubes, and centrifuged in a Beckman microfuge (Beckman Instruments, Inc., Spinco Div., Palo Alto, Calif.) at $10,000 \mathrm{rpm}$ for $20 \mathrm{~s}$. The supernate was quickly removed by aspiration and the pellet was suspended in $100 \mu \mathrm{l}$ of ice-cold 5\% trichloroacetic acid (TCA). The entire suspension was quantitatively transferred to counting vials with the aid of Toluene-Triton X-100 (Rohm and Haas Co., Philadelphia, Pa.) scintillation counting fluid. Samples were counted in a betascintillation counter with automatic quench correction.

In preliminary experiments, uptake of ${ }^{3} \mathrm{H}-2-D G$ was shown to be linear during at least the $1 \mathrm{st} h$ of incubation. Therefore, a 15-min period of incubation with ${ }^{3} \mathrm{H}-2-\mathrm{DG}$ was employed in all subsequent experiments.

$\left[3-\mathrm{O}-{ }^{3} \mathrm{H}\right] \mathrm{Methylglucose}$ uptake. In experiments to assess the effect of $\mathrm{T}_{3}$ on the uptake of the nonmetabolized sugar, 3-Omethyl-D-glucose (3-O-MG), cells were prepared as above and were equilibrated and preincubated with or without $T_{3}$ as in experiments with ${ }^{3} \mathrm{H}$-2-DG. At the end of preincubation periods, ${ }^{3} \mathrm{H}-3-O-M G(3 \mu \mathrm{Ci} / \mathrm{ml} ; 80.8 \mathrm{Ci} / \mathrm{mmol}$ sp act) was added, and the incubation continued. At specified intervals thereafter, aliquots were removed and processed for measurement of the ${ }^{3} \mathrm{H}$ content of the thymocytes as described above.

Corrections for occluded extracellular fluid. Because the final cell pellets inevitably contained occluded extracellular fluid, preliminary experiments were conducted to assess the efficacy of using $\mathrm{D}-\left[{ }^{3} \mathrm{H}\right]$ mannitol as an extracellular fluid marker. Cell suspensions were incubated with $\mathrm{D}-\left[{ }^{3} \mathrm{H}\right]$ mannitol (3 $\mu \mathrm{Ci} / \mathrm{ml} ; 24 \mathrm{Ci} / \mathrm{mmol} \mathrm{sp}$ act) for varying periods and the content of ${ }^{3} \mathrm{H}$ in cell pellets was measured. No change in ${ }^{3} \mathrm{H}$ content of pellets obtained between 1 and $60 \mathrm{~min}$ of incubation was observed, and values were the same whether the incubation temperature was $4^{\circ}$ or $37^{\circ} \mathrm{C}$. Pellet contents of $\mathrm{D}-\left[{ }^{3} \mathrm{H}\right]$ mannitol were consistently in the order of $0.45-$ $0.60 \%$ of the total ${ }^{3} \mathrm{H}$ present in the $200 \mu \mathrm{l}$ of cell suspension from which the pellets were derived, and were unaffected by the presence of $T_{3}$. The findings indicated that in this system $\left[{ }^{3} \mathrm{H}\right]$ mannitol is confined to the extra-cellular space.

${ }^{2} \mathrm{~L}$-[2-deoxy- $\left.{ }^{3} \mathrm{H}\right]$ glucose, D- $\left[{ }^{3} \mathrm{H}\right]$ mannitol, [3-O- $\left.{ }^{3} \mathrm{H}\right]$ methylglucose, D-[glucose-6- $\left.{ }^{14} \mathrm{C}\right]$ phosphate, and $\left[{ }^{3} \mathrm{H}\right]$ leucine were purchased from New England Nuclear (Boston, Mass.). D-Glucose-6-phosphate, 2-deoxyglucose-6-phosphate, puromycin, cycloheximide, L-3,5,3'-triiodothyronine, L-thyroxine, 3,5-diiodothyronine, and L-thyronine were purchased from Sigma Chemical Co. (St. Louis, Mo.). 3,3',5-Triiodothyronine was kindly provided by Baxter-travenol Laboratories (Morton Grove, Ill.).
Consequently, in each experiment, parallel cell suspensions containing $\left[{ }^{3} \mathrm{H}\right]$ mannitol, rather than ${ }^{3} \mathrm{H}-2-\mathrm{DG}$ or ${ }^{3} \mathrm{H}-3-\mathrm{O}-\mathrm{MG}$, were incubated so that corrections for occluded extracellular fluid in the cell pellets could be made.

Phosphorylation of 2-DG. In experiments to determine the percentage of accumulated ${ }^{3} \mathrm{H}-2-\mathrm{DG}$ that had undergone phosphorylation within the thymocytes, cell suspensions were prepared, equilibrated, and preincubated with or without $\mathrm{T}_{3}$ according to the techniques described above. Media were then enriched with ${ }^{3} \mathrm{H}-2-\mathrm{DG}$ in concentrations ranging between $0.36 \mu \mathrm{M}$ and $8 \mathrm{mM}$. 15 min later, triplicate aliquots of $200 \mu \mathrm{l}$ of suspension were removed for measurement of total ${ }^{3} \mathrm{H}$-2-DG uptake and duplicate $500-\mu \mathrm{l}$ aliquots were removed at the same time for fractionation of ${ }^{3} \mathrm{H}-2-\mathrm{DG}$ into phosphorylated and nonphosphorylated moieties. The latter suspensions were centrifuged, the cell pellets were dispersed into 5\% cold TCA and were resedimented. Supernates were enriched with $2 \mathrm{mM}$ 2-DG-6-phosphate carrier and were then brought to $\mathrm{pH} 7.0$ with concentrated $\mathrm{NaOH}$. Somogyi reagent (15) was added, and the mixture was centrifuged. Aliquots of the supernate were taken for measurement of nonphosphorylated ${ }^{3} \mathrm{H}-2-\mathrm{DG}$, and the quantity of ${ }^{3} \mathrm{H}-$ 2-DG-6-phosphate calculated as the difference between total ${ }^{3} \mathrm{H}$ in the cell pellet and ${ }^{3} \mathrm{H}$ in the Somogyi supernate.

Control experiments in which a $5 \%$ solution of TCA was first enriched with $\left[{ }^{3} \mathrm{H}\right]$ glucose-6-phosphate and the foregoing procedure was then carried out revealed that $98 \%$ of the ${ }^{3} \mathrm{H}$ was contained in the final precipitate.

Kinetics of 2-DG accumulation. In the experiments to assess the phosphorylation of ${ }^{3} \mathrm{H}-2-\mathrm{DG}$ described above, triplicate $200-\mu$ l aliquots of cell suspension were removed 10 min after varying concentrations of ${ }^{3} \mathrm{H}-2-\mathrm{DG}$ had been added. Total ${ }^{3} \mathrm{H}$ uptake was measured, and the data obtained were subjected to analysis.

Leucine incorporation. To assess the effect of $\mathrm{T}_{3}$ in vitro on leucine incorporation into thymocyte protein, cell suspensions were prepared and equilibrated in the standard manner, and were then preincubated with or without $T_{3}$ for varying periods. Thereafter, $\left[{ }^{3} \mathrm{H}\right] l$ leucine $(84 \mathrm{Ci} / \mathrm{mmol}$ sp act) was added in a concentration of $1 \mu \mathrm{Ci} / \mathrm{ml}$, and incubations were continued for $30 \mathrm{~min}$. The entire suspension was transferred to centrifuge tubes, cells were sedimented, resuspended in $3 \mathrm{ml}$ of $5 \%$ cold TCA, resedimented, and washed twice again with $5 \%$ cold TCA. After a final centrifugation, the sediment was taken up in Toluene-Triton X-100 counting fluid and its content of ${ }^{3} \mathrm{H}$ measured.

Statistical analyses. As appropriate to the experimental design, statistical analyses were performed with Student's $t$ test, the paired $t$ test, or by Dunnett's test (16).

\section{RESULTS}

Latency of $T_{3}$ effect. Initial experiments were conducted to determine whether $\mathrm{T}_{3}$ would influence the uptake of 2-DG by thymocytes, and, if so, how long a period of exposure of cells to $\mathrm{T}_{3}$ would be required. For these experiments, cells were incubated with $T_{3}$ at a concentration of $1 \mu \mathrm{M}$, because this had been shown to enhance the accumulation of cycloleucine by thymocytes under similar in vitro conditions (11). Control and $\mathrm{T}_{3}$-enriched thymocyte suspensions were preincubated for varying periods, after which ${ }^{3} \mathrm{H}-2-D G$ was added and its uptake by the cells measured 15 min later.

As compared with values in corresponding controls, 
uptake of ${ }^{3} \mathrm{H}-2-\mathrm{DG}$ in specimens preincubated with $\mathrm{T}_{3}$ for 30,60 , and 120 min was significantly increased in each of five individual experiments (Fig. 1). In specimens preincubated with $\mathrm{T}_{3}$ for $15 \mathrm{~min}$, a significant increase in ${ }^{3} \mathrm{H}-2-\mathrm{DG}$ uptake was not seen in any of the five experiments; however, when mean values for control and $\mathrm{T}_{3}$-treated specimens of the five experiments were compared by the paired $t$ test, a significant increase $(P<0.05)$ was demonstrable. Hence, at a concentration of $1 \mu \mathrm{M}$, a significant stimulatory effect of $T_{3}$ on 2-DG accumulation by thymocytes was seen after cells have been exposed to the hormone for a total of only $30 \mathrm{~min}$.

In control specimens, the uptake of 2-DG remained constant after preincubation periods of from 15 to 30 min, increased slightly in cells preincubated for $1 \mathrm{~h}$, and was substantially increased in cells preincubated for $2 \mathrm{~h}$. Consequently, the percentage stimulation of 2-DG uptake produced by $\mathrm{T}_{3}$ was greatest in cells preincubated for $1 \mathrm{~h}$, and this period of preincubation with $T_{3}$ was selected for most subsequent studies of the $\mathrm{T}_{3}$ effect.

Dose-response relationship. As determined in five experiments in which cells were preincubated with or without $\mathrm{T}_{3}$ for $1 \mathrm{~h}$, uptake of 2-DG by thymocytes displayed a linear log dose-response relationship at $\mathrm{T}_{3}$ concentrations up to $10 \mu \mathrm{M}$ (Fig. 2). The lowest concentration of $\mathrm{T}_{3}$ that produced significant stimulation of 2 -DG uptake $(P<0.05)$ was $1 \mathrm{nM}$, and this was true

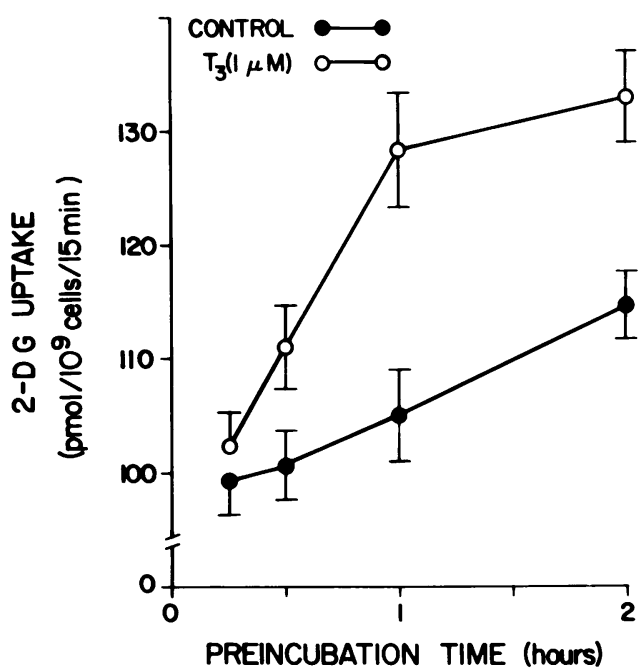

FIgUre 1 Time-course of the $T_{3}$ effect on the accumulation of ${ }^{3} \mathrm{H}-2$-DG by rat thymocytes in vitro. Cells were preincubated with $\mathrm{T}_{3}(1 \mu \mathrm{M})$ for the periods indicated. ${ }^{3} \mathrm{H}-2-\mathrm{DG}$ was then added and its accumulation in the cells measured 15 min later. Values shown are mean $\pm S E$ of those obtained in five experiments in which quadruplicate vessels were incubated for each experimental point. Statistically significant enhancement of 2 -DG accumulation $(P<0.05)$ was present in cells preincubated for $15 \mathrm{~min}$.

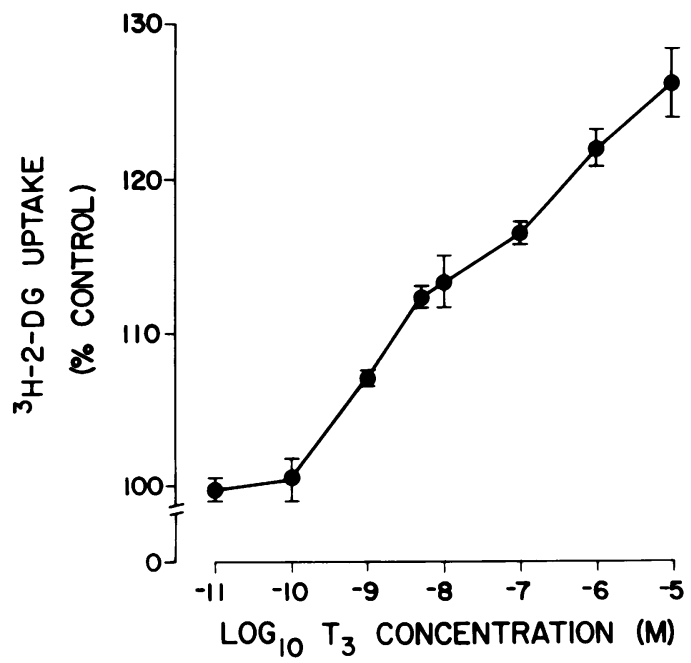

FIGURE 2 Dose-response curves for the $\mathrm{T}_{3}$ effect on ${ }^{3} \mathrm{H}-2-\mathrm{DG}$ accumulation by rat thymocytes. Cells were preincubated with the indicated concentrations of $T_{3}$ for $1 \mathrm{~h}$, and the 15min accumulation of ${ }^{3} \mathrm{H}-2-\mathrm{DG}$ was then measured. Values are expressed as a percent of those found in $T_{3}$-free controls and represent the mean $\pm \mathrm{SE}$ of those obtained in five experiments in which quadruplicate vessels in each group were studied.

both for individual experiments and when data from the five experiments were pooled and analyzed on the basis of either absolute values or percentage increases from control.

Phosphorylation of 2-DG. Two experiments were performed in which thymocytes were preincubated for $1 \mathrm{~h}$ with or without $1 \mu \mathrm{M} \mathrm{T}$, and the total accumulation and percentage phosphorylation of ${ }^{3} \mathrm{H}-2$-DG were measured $15 \mathrm{~min}$ after exposure of cells to varying conconcentrations of 2-DG. At all concentrations of 2-DG tested, total accumulation of ${ }^{3} \mathrm{H}-2-\mathrm{DG}$ was greater in cells preincubated with $T_{3}$ than in those not preincubated $(P<0.02)$. Percentage phosphorylation of accumulated 2 -DG was $\cong 98 \%$ in specimens incubated at the lowest concentration of 2-DG $(0.36 \mu \mathrm{M})$, remained almost constant over a 347 -fold increase in 2-DG concentration to $0.125 \mathrm{mM}$, and then declined progressively to $\cong 80 \%$ in specimens incubated with the highest concentrations of 2-DG tested $(8 \mathrm{mM})$ (Fig. 3 ). Values for the percentage phosphorylation of accumulated 2-DG were not detectably influenced by preincubation with $1 \mu \mathrm{M} \mathrm{T}_{3}$.

Kinetics of 2-DG accumulation. In the two experiments described immediately above, the effect of $\mathrm{T}_{3}$ on the kinetics of 2-DG accumulation was evaluated from data obtained $10 \mathrm{~min}$ after addition of varying concentrations of ${ }^{3} \mathrm{H}-2-\mathrm{DG}$. As in specimens incubated for $15 \mathrm{~min}$, total accumulation of 2-DG was higher in $\mathrm{T}_{3}$-treated than in control specimens at all concentrations of 2 -DG employed $(P<0.02)($ Fig. 4). Despite the 


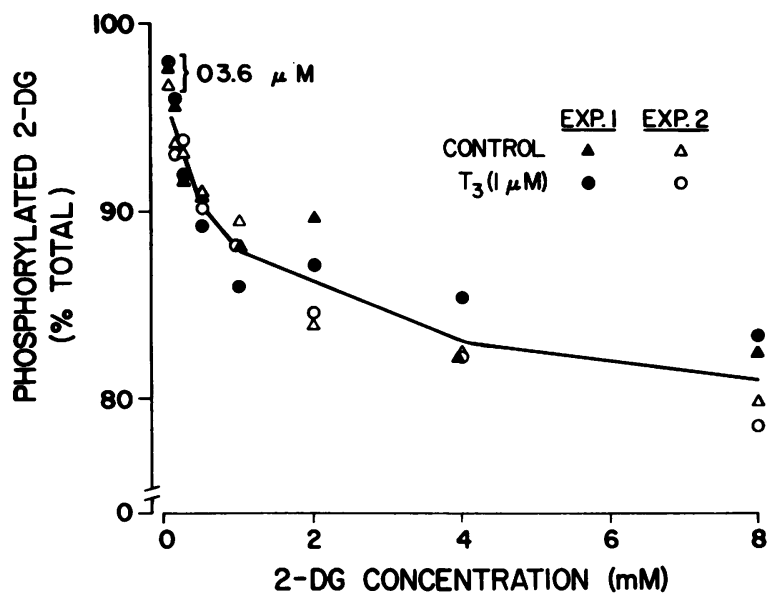

FIGURE 3 Phosphorylation of accumulated 2-DG by rat thymocytes in the presence and absence of $T_{3}$. Shown are the results of two experiments in which quadruplicate vessels were studied for each experimental point. Cells were preincubated with or without $\mathrm{T}_{3}(1 \mu \mathrm{M})$ for $1 \mathrm{~h}$, after which ${ }^{3} \mathrm{H}-2-D G$ and unlabeled 2-DG were added for $15 \mathrm{~min}$ at the concentrations indicated. Cells were then harvested and the accumulated 2-DG was fractionated into phosphorylated and nonphosphorylated moieties as described in the text.

complex nature of 2-DG accumulation, which involves both transport into the cell and phosphorylation, we attempted to apply conventional kinetic analysis to the foregoing data, as others have done with respect to the accumulation of 2-DG in other tissues (17-20). With computer assistance, least square fits to hyperbolic

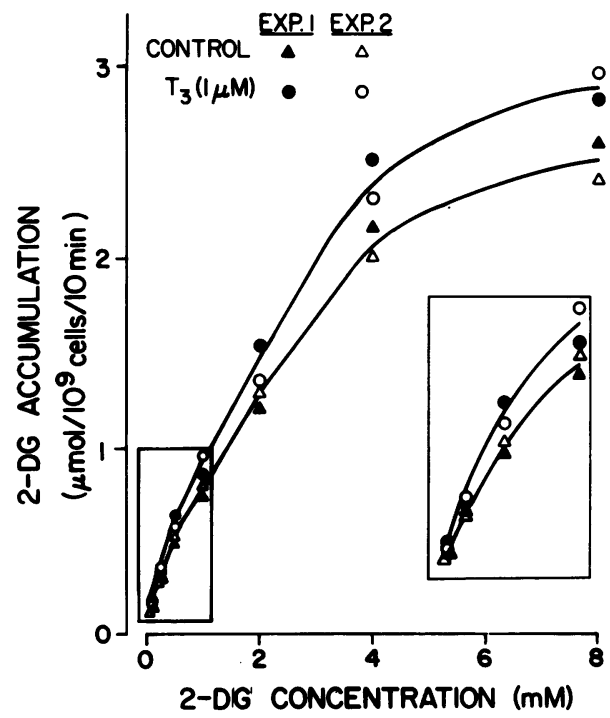

Figure 4 Saturation studies of the effect of $T_{3}$ on the accumulation of 2-DG by rat thymocytes in vitro. Incubation conditions were the same as those for Fig. 3, except that samples for measurement of total 2-DG accumulation were withdrawn at $10 \mathrm{~min}$. functions were calculated from the pooled data for control and $\mathrm{T}_{3}$-treated groups, respectively, from the two experiments. These analyses revealed no significant difference in values of the apparent $K_{\mathrm{m}}$ in the $\mathrm{T}_{3}$-treated $(2.77 \pm 0.25 \mathrm{mM}$; mean $\pm \mathrm{SD})$ and the control $(3.00 \pm 0.35 \mathrm{mM})$ groups, values in both groups being well within the range of the $K_{\mathrm{m}}$ for 2-DG accumulation reported in other tissues (17-20). Values for apparent $\mathrm{V}_{\max }$ were significantly higher $(P<0.02)$, however, in $\mathrm{T}_{3}$-treated $\left(3.91 \pm 0.25 \mu \mathrm{mol} / 10^{9}\right.$ cells per $\left.10 \mathrm{~min}\right)$ than in control $\left(3.45 \pm 0.28 \mu \mathrm{mol} / 10^{9}\right.$ cells per $\left.10 \mathrm{~min}\right)$ groups.

3-O-MG accumulation. In each of two experiments, quadruplicate samples of thymocytes were preincubated with $\mathrm{T}_{3}(1 \mathrm{nM}$ or $1 \mu \mathrm{M})$ for $1 \mathrm{~h}$, after which ${ }^{3} \mathrm{H}-3-\mathrm{O}-\mathrm{MG}$ was added and its cellular accumulation measured at intervals varying between $30 \mathrm{~s}$ and $30 \mathrm{~min}$ later. Three additional experiments were conducted in which the effect of $\mathrm{T}_{3}$ only on accumulation of ${ }^{3} \mathrm{H}-3-\mathrm{O}-\mathrm{MG}$ during $30 \mathrm{~s}$ was assessed. Analysis of the data revealed that $1 \mu \mathrm{M} \mathrm{T}$ increased ${ }^{3} \mathrm{H}-3-O-\mathrm{MG}$ accumulation at all of the time intervals studied, and that $1 \mathrm{nM} \mathrm{T}$ did so at all except that 30 -min interval. This was true whether data from individual experiments were analyzed or whether the results of replicate studies were pooled and analyzed together. As seen in Fig. 5, the proportionate effect of both $1 \mu \mathrm{M}$ and 1 $\mathrm{nM}$ decreased over the time that the cells were exposed to 3-O-MG.

$\left[{ }^{3} \mathrm{H}\right]$ Leucine incorporation. In four experiments, thymocytes were preincubated for 1 or $2 \mathrm{~h}$ in media either lacking $T_{3}$ or containing $T_{3}$ at concentrations of

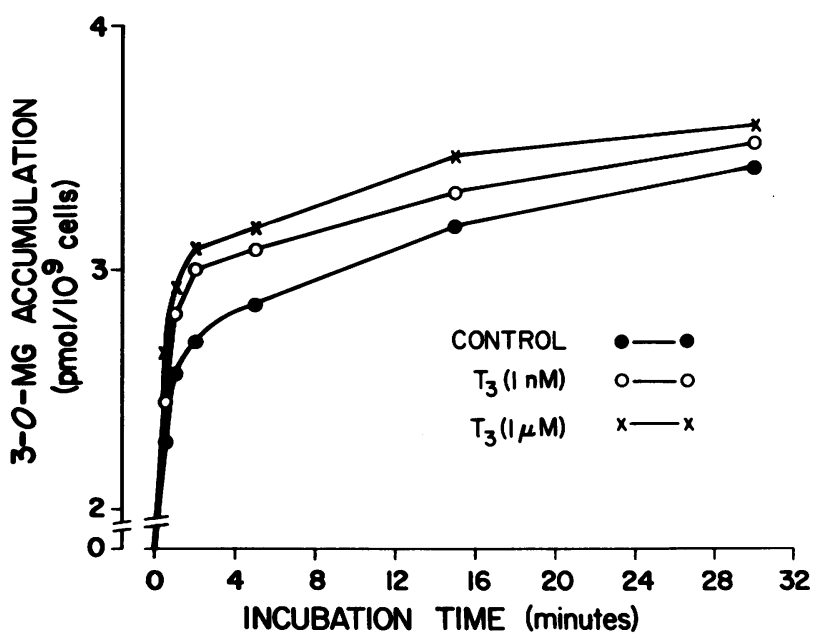

Figure 5 The effect of $\mathrm{T}_{3}$ on the accumulation of 3-O-MG by rat thymocytes in vitro. Results represent the pooled data from two experiments in which quadruplicate samples were incubated for each experimental point. Cells were preincubated with $T_{3}(1 \mathrm{nM}$ or $1 \mu \mathrm{M})$ for $1 \mathrm{~h}$, after which ${ }^{3} \mathrm{H}-3-\mathrm{O}-\mathrm{MG}$ was added, and its accumulation by cells measured at the indicated intervals thereafter. 
$1 \mathrm{nM}$ or $1 \mu \mathrm{M}$. The incorporation of $\left[{ }^{3} \mathrm{H}\right]$ leucine over the subsequent $30 \mathrm{~min}$ was then measured in quadruplicate aliquots from each experimental group.

$\left[{ }^{3} \mathrm{H}\right]$ Leucine incorporation was significantly lower in cells preincubated for $2 \mathrm{~h}$ than in those preincubated for $1 \mathrm{~h}$, regardless of whether or not $T_{3}$ was present. However, for each period of incubation, values of $\left[{ }^{3} \mathrm{H}\right]$ leucine accumulation were not changed by $\mathrm{T}_{3}$ at either concentration studied (Table I).

Inhibition of protein synthesis. Experiments were conducted to determine the conditions under which puromycin and cycloheximide each would produce profound inhibition of amino acid incorporation by thymocytes. When thymocytes were preincubated with puromycin $(100 \mu \mathrm{g} / \mathrm{ml})$ for $10 \mathrm{~min}$, incorporation of $\left[{ }^{3} \mathrm{H}\right]$ leucine into TCA-precipitable moieties during the ensuing $30 \mathrm{~min}$ was only $5 \%$ of that in control specimens. A similar preincubation exposure to cycloheximide $(100 \mu \mathrm{g} / \mathrm{ml})$ decreased $\left[{ }^{3} \mathrm{H}\right]$ leucine incorporation by $96 \%$. This effect was not accompanied by a change in cell viability, because $95 \%$ of the thymocytes retained their ability to exclude nigrosin during incubation periods of $150 \mathrm{~min}$, regardless of whether or not cycloheximide or puromycin was present.

12 experiments were then performed in which thymocytes were variously preincubated for $10 \mathrm{~min}$ in the absence or presence of puromycin $(100 \mu \mathrm{g} / \mathrm{ml})$, and for an additional $1 \mathrm{~h}$ in the absence or presence of $\mathrm{T}_{3}(1 \mathrm{nM}$ or $1 \mu \mathrm{M})$, and in which the uptake of ${ }^{3} \mathrm{H}-2-\mathrm{DG}$ was then assessed. Puromycin alone produced a significant $(P<0.01), \cong 20 \%$, inhibition of 2-DG uptake (Table II). Both concentrations of $T_{3}$ significantly increased 2-DG uptake whether or not puromycin was present, and the percentage stimulation of

TABLE I

The Effect of Preincubation with $T_{3}$ on the In Vitro Incorporation of $\left[{ }^{3} \mathrm{H}\right]$ Leucine into Protein by Rat Thymocytes*

\begin{tabular}{|c|c|c|}
\hline & $\begin{array}{c}\mathrm{T}_{3} \\
\text { concentration }\end{array}$ & $\begin{array}{l}{\left[{ }^{3} \mathrm{H}\right] \text { Leucine }} \\
\text { incorporation }\end{array}$ \\
\hline 60 -min preincubation with $T_{3}$ & $\begin{array}{l}0 \\
1 \mathrm{nM} \\
1 \mu \mathrm{M}\end{array}$ & $\begin{array}{l}1.90 \pm 0.03 \\
1.81 \pm 0.02 \\
1.82 \pm 0.04\end{array}$ \\
\hline 120 -min preincubation with $T_{3}$ & $\begin{array}{l}0 \\
1 \mathrm{nM} \\
1 \mu \mathrm{M}\end{array}$ & $\begin{array}{l}1.24 \pm 0.05 \\
1.35 \pm 0.02 \ddagger \\
1.25 \pm 0.05\end{array}$ \\
\hline
\end{tabular}

* Cells were preincubated with $\mathrm{T}_{3}$ at the indicated concentrations for the periods of time shown. $\left[{ }^{3} \mathrm{H}\right]$ Leucine was then added, and its incorporation (expressed in picomoles per $10^{9}$ cells) into protein was measured $30 \mathrm{~min}$ later. Values shown are mean $\pm \mathrm{SE}$ of those obtained in four experiments in which quadruplicate vessels in each experimental group were studied.

$\ddagger P<0.02$ vs. corresponding 60 -min incubation group.
TABLE II

Failure of Puromycin to Inhibit the In Vitro Stimulatory Effect of $T_{3}$ on the Accumulation of 2-DG by Rat Thymocytes*

\begin{tabular}{cccr}
\hline $\begin{array}{c}\mathrm{T}_{3} \\
\text { concentration }\end{array}$ & $\mathrm{PM}$ & $\begin{array}{c}{ }^{3} \mathrm{H}-2-\mathrm{DG} \\
\text { accumulation }\end{array}$ & \multicolumn{1}{c}{$\begin{array}{c}\mathrm{T}_{3} \\
\text { effect }\end{array}$} \\
\hline- & - & $102 \pm 3$ & \\
- & + & $84 \pm 4 \ddagger$ & $8.8 \pm 0.6$ \\
$1 \mathrm{nM}$ & - & $111 \pm 3 \S$ & $8.3 \pm 0.4$ \\
$1 \mathrm{nM}$ & + & $91 \pm 2 \ddagger \S$ & $17.6 \pm 0.7$ \\
$1 \mu \mathrm{M}$ & - & $120 \pm 3 \S$ & $20.6 \pm 1.6$ \\
$1 \mu \mathrm{M}$ & + & $101 \pm 4 \ddagger \S$ & \\
\hline
\end{tabular}

* Cells were preincubated with puromycin $(\mathrm{PM} ; 100 \mu \mathrm{g} / \mathrm{ml})$ for $10 \mathrm{~min}$ and for an additional 60-min period with $\mathrm{T}_{3}$ at the indicated concentrations. ${ }^{3} \mathrm{H}-2-\mathrm{DG}$ was then added and its accumulation (expressed in picomoles per $10^{9}$ cells) measured $15 \mathrm{~min}$ later. $\mathrm{T}_{3}$ effect shown is the percent increase over values in the corresponding $T_{3}$-free group. Values shown are mean $\pm \mathrm{SE}$ of those obtained in 12 experiments in which quadruplicate samples in each experimental group were studied.

$\ddagger P<0.01$ vs. corresponding PM-free group.

$\S P<0.01$ vs. corresponding $T_{3}$-free group.

2-DG uptake produced by $\mathrm{T}_{3}$ was unaffected by puromycin. In similar experiments, cycloheximide (100 $\mu \mathrm{g} / \mathrm{ml}$ ) decreased ${ }^{3} \mathrm{H}-2-\mathrm{DG}$ accumulation by $\cong 10 \%$, but failed to affect the proportionate increase in ${ }^{3} \mathrm{H}-2-\mathrm{DG}$ accumulation induced by $\mathrm{T}_{3}(1 \mu \mathrm{M})$ (Table III).

Dose-response curves for the effect on ${ }^{3} \mathrm{H}-2-\mathrm{DG}$ accumulation of several compounds related to $T_{3}$ revealed the following order of stimulatory potency: $T_{3}$ $>$ thyroxine $\left(\mathrm{T}_{4}\right)>3,3^{\prime}, 5^{\prime}$-triiodothyronine $\left(\mathrm{rT}_{3}\right)>3,5$ diiodothyronine $\left(3,5-\mathrm{T}_{2}\right)>$ thyronine (Fig. 6). Precise quantitative comparisons were not possible because of poor parallelism of dose-response curves.

\section{DISCUSSION}

The present studies seem clearly to have shown that, in thymocytes freshly isolated from weanling rats, $\mathrm{T}_{3}$ in vitro stimulates the accumulation of two ${ }^{3} \mathrm{H}$ labeled analogues of glucose, 2-DG, and 3-O-MG. In the case of 2-DG, this effect of $\mathrm{T}_{3}$ is demonstrable in cells exposed to $T_{3}$ for a total of only $30 \mathrm{~min}$, i.e., after $15 \mathrm{~min}$ of preincubation with $\mathrm{T}_{3}$ and $15 \mathrm{~min}$ of incubation with ${ }^{3} \mathrm{H}-2-\mathrm{DG}$. Significant stimulation of 2-DG accumulation was produced by $\mathrm{T}_{3}$ at a concentration of $1 \mathrm{nM}$, with a linear log dose response up to $\mathrm{T}_{3}$ concentrations of $10 \mu \mathrm{M}$, at which concentration accumulation of 2 -DG was increased by $\cong 25 \%$. Although not extensively explored, thyroxine, $3,3^{\prime}, 5^{\prime}$ triiodothyronine, and 3,3'-diiodothyronine were also capable of stimulating 2-DG uptake, and the potency of these compounds, relative to that of $T_{3}$, was similar 
TABLE III

Failure of Cycloheximide to Inhibit the In Vitro Stimulatory Effect of $T_{3}$ on the Accumulation of 2-DG by Rat Thymocytes*

\begin{tabular}{|c|c|c|c|c|}
\hline & $\mathrm{T}_{3}$ & $\mathrm{CH}$ & $\begin{array}{c}{ }^{3} \mathrm{H}-2-\mathrm{DG} \\
\text { accumu- } \\
\text { lation }\end{array}$ & $\begin{array}{c}\mathbf{T}_{3} \\
\text { effect }\end{array}$ \\
\hline \multirow{4}{*}{$\begin{array}{l}\text { 30-min preincubation } \\
\text { with } \mathrm{T}_{3}\end{array}$} & & & & \\
\hline & + & - & $\begin{array}{l}100 \pm 1 \\
112 \pm 1 t\end{array}$ & $12.0 \pm 1.1$ \\
\hline & - & + & $89 \pm 2 \S$ & \\
\hline & + & + & $101 \pm 11 \S$ & $13.5 \pm 1.4$ \\
\hline \multirow{5}{*}{$\begin{array}{l}\text { 60-min preincubation } \\
\text { with } T_{3}\end{array}$} & & & & \\
\hline & - & - & $98 \pm 2$ & \\
\hline & + & - & $116 \pm 3^{\prime \prime}$ & $18.4 \pm 1.3$ \\
\hline & - & + & $89 \pm 1 \S$ & \\
\hline & + & + & $103 \pm 2 \S "$ & $15.7 \pm 1.4$ \\
\hline
\end{tabular}

* Cells were preincubated for $10 \mathrm{~min}$ with cycloheximide $(\mathrm{CH} ; 100 \mu \mathrm{g} / \mathrm{ml})$ and then, for an additional period as indicated, with $\mathrm{T}_{3}(1 \mu \mathrm{M}) .{ }^{3} \mathrm{H}-2-\mathrm{DG}$ was then added, and its accumulation (expressed in picomoles per $10^{9}$ cells) measured $15 \mathrm{~min}$ later. $\mathrm{T}_{3}$ effect shown is the percent increase over values in the corresponding $T_{3}$-free group. Values shown are mean $\pm \mathrm{SE}$ of those obtained in four experiments in which quadruplicate samples in each experimental group were studied.

$\ddagger P<0.05$ vs. corresponding $\mathrm{T}_{3}$-free group.

$\$ P<0.01$ vs. corresponding $\mathrm{CH}$-free group.

" $P<0.01$ vs. corresponding $T_{3}$-free group.

in rank order to that seen in a variety of other thyroid hormone-responsive systems (see review, reference 21).

At concentrations of $1 \mathrm{nM}$ and $1 \mu \mathrm{M}, \mathrm{T}_{3}$ had no effect on the incorporation of $\left[{ }^{3} \mathrm{H}\right]$ leucine into the protein of thymocytes, even after cells had been preincubated with $\mathrm{T}_{3}$ for as long as $2 \mathrm{~h}$. Moreover, when thymocytes were preincubated with puromycin or cycloheximide at concentrations sufficient to reduce subsequent $\left[{ }^{3} \mathrm{H}\right]$ leucine incorporation by $\cong 95 \%$, basal 2-DG accumulation did decrease, but the proportionate increase in 2-DG accumulation produced by $T_{3}$ was not altered. Thus, the data strongly indicate that the prompt effect of $T_{3}$ on 2-DG accumulation is unrelated to any effect on new protein synthesis.

Cellular uptake of 2-DG is the result of two functions, transport of 2-DG into the cell and its subsequent phosphorylation by hexokinase. Further metabolism of 2-DG does not occur, and the 2-DG-6-phosphate formed is retained within the cell $(22,23)$. At the very low concentration of 2-DG used in the present studies, transport, rather than phosphorylation, is generally the rate-limiting factor in 2-DG accumulation $(24,25)$. Hence, it would appear that $T_{3}$ must have increased 2-DG uptake by increasing its rate of entry into the cell. This conclusion was verified in two sets of ad-

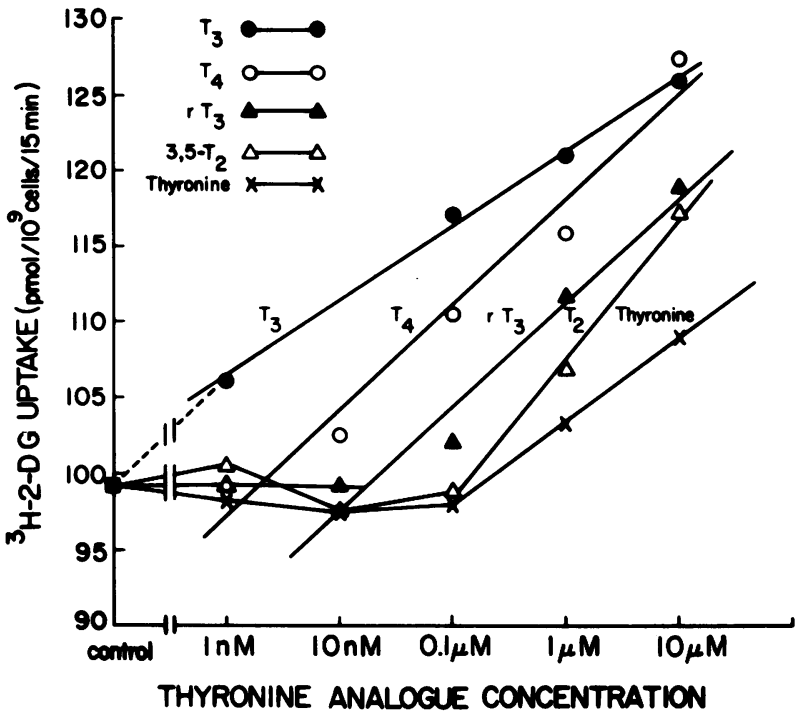

FIGURE 6 The effect of various thyroxine analogues (levorotatory isomers) on the uptake of ${ }^{3} \mathrm{H}-2-\mathrm{DG}$ by rat thymocytes in vitro. Results shown are the mean of values obtained in quadruplicate vessels and are typical of those obtained in two or more experiments. $\mathrm{T}_{4}$, thyroxine; $\mathrm{rT}_{3}, 3,3^{\prime}, 5^{\prime}$-triiodothyronine; $3,5-T_{2}$, thyronine.

ditional experiments. First, it was shown that $T_{3}$ enhanced the accumulation of ${ }^{3} \mathrm{H}-2-\mathrm{DG}$ over a very wide range of extracellular 2-DG concentrations and that this increase was not accompanied by a change in the proportion of accumulated ${ }^{3} \mathrm{H}-2-D G$ that had undergone phosphorylation. This effect is similar to that of insulin in fat, muscle, and lymphoid tissue, where insulin also increases sugar uptake without changing phosphorylation (26-31). Second, direct evidence to the point was obtained in studies with the second analogue of glucose examined, 3-O-MG. This sugar has been shown to use the same transport mechanism as glucose and 2-DG do (17-19), but does not undergo phosphorylation and remains free to diffuse out of the cell $(32,33)$. The effect of $\mathrm{T}_{3}$ on $3-O-\mathrm{MG}$ uptake was therefore assessed after very short periods of exposure to the ${ }^{3} \mathrm{H}$-labeled sugar in order to observe the process of inward transport and to minimize any effects of ${ }^{3} \mathrm{H}-3-\mathrm{O}-\mathrm{MG}$ efflux on the results obtained. A stimulatory effect of $T_{3}$ was evident in cells exposed to ${ }^{3} \mathrm{H}-3-\mathrm{O}-\mathrm{MG}$ for $30 \mathrm{~s}$, confirming the effect of $\mathrm{T}_{3}$ on inward transport. The proportionate effect decreased with time, as would be expected from the increasing role of ${ }^{3} \mathrm{H}-3-\mathrm{O}-\mathrm{MG}$ efflux as a determinant of net accumulation. Taken together, these data provide strong evidence that $T_{3}$ acts to enhance the inward transport of sugars in this system.

Cellular accumulation of 2-DG is a complex process, which involves both transport of the sugar into the cell 
and its subsequent phosphorylation, making conventional kinetic analysis difficult. Nevertheless, accumulation of 2-DG has been studied in this manner by other workers in other tissues (17-20,34-36), and we have attempted to do the same in regard to the accumulation of 2-DG by rat thymocytes. Such analyses suggested that the stimulatory effect of $T_{3}$ was the result of an increase in the $\mathrm{V}_{\max }$ of 2-DG transport, rather than a change in $K_{\mathrm{m}}$. In this respect, the effect of $T_{3}$ on sugar transport in thymocytes again resembles that of insulin in muscle and fat cells (20, $34-36$ ); this may relate to preliminary observations we have made which indicate that the minimum concentration of $\mathrm{T}_{3}$ necessary to stimulate 2-DG accumulation is reduced in the presence of insulin. ${ }^{3}$

A primary consideration with respect to the present findings is whether or not they reflect an action of thyroid hormone that takes place under physiological circumstances in vivo. We are unaware of any data concerning the effect of thyroid hormone insufficiency or excess, per se, on the rate of glucose uptake by tissues in the living organism. Although the rate of disappearance from plasma of administered glucose and the rate of generation of products of glucose metabolism is decreased or accelerated in hypothyroid and hyperthyroid states, respectively $(37-41)$, it is by no means certain that these changes reflect either a change in glucose uptake by the cells or a direct action of the thyroid hormones. Indeed, a recent report indicates that hypothyroidism does not affect the transport of $3-O-M G$ in isolated adipocytes of the rat (42).

The major reason to question the physiological relevance of the presently described effect of $T_{3}$ is the high concentration required to produce this effect, relative to the concentration of the $T_{3}$ presumed to be acting upon the tissues in the living animal (free $\mathrm{T}_{3}$ concentration $\cong 5 \rho \mathrm{M}$ ). Although some in vitro effects of $\mathrm{T}_{3}$ are demonstrable at concentrations approaching the physiological, it is often the case that in vitro actions of the thyroid (and other) hormones that appear to have physiological relevance require unphysiologically high concentrations for their prompt in vitro demonstration. For example, in the rat, the lipolytic activity of adipose tissue and the degree to which it is stimulated by epinephrine are clearly influenced by the thyroid state of the animal (see reviews, references 43-46). Nevertheless, $T_{3}$-induced enhancement of these activities in vitro requires concentrations approximately six orders of magnitude greater than the concentration of free $T_{3}$ presumed to be present in vivo, and three orders of magnitude greater than the concentration of $T_{3}$ required to produce the effect that we

${ }^{3}$ Segal, J., C. Ruegsegger, and S. H. Ingbar. Unpublished observations. are describing (47-49). A second example is provided by studies that have demonstrated an increase in hepatic mitochondrial protein synthesis after exposure to $\mathrm{T}_{3}$, in which the in vivo sensitivity to this effect was estimated to be $\cong 10,000$ times higher than the sensitivity in vitro $(50-52)$. Finally, concentrations of $\mathrm{T}_{3} \cong 100$-fold higher than those required to enhance 2-DG uptake in thymocytes are necessary to produce inhibition of the adenylate cyclase response to exogenous thyrotropin by bovine thyroid membranes. The concentration of $T_{3}$ required for the latter effect $(50 \mu \mathrm{M})$ is about six orders of magnitude greater than the presumed free $T_{3}$ concentration in vivo; nevertheless, a seemingly similar inhibition of thyroid adenylate cyclase response to exogenous thyrotropin could be produced by the administration of only 2.5 $\mu \mathrm{g}$ of $\mathrm{T}_{3}$ to the mouse $(53,54)$.

In addition to the requirement that in vitro systems impose that any effect of $T_{3}$ be prompt, which might in itself increase the concentration required, in vitro systems are often impaired in the sense that they may lack other factors that act in a permissive, synergistic, or potentiating manner. With respect to the accumulation of 2-DG by rat thymocytes, we have shown that epinephrine and insulin are stimulatory when added alone, and that separately or together they enhance the response to $T_{3}$. Thus, the minimally effective dose of $\mathrm{T}_{3}$ is reduced by one order of magnitude, i.e., to $\cong 0.1 \mathrm{nM}$, if epinephrine is present in the medium, and is decreased still further (to $\cong 10 \mathrm{pM}$ ) by the concomitant addition of insulin. ${ }^{3}$ Hence, under the appropriate conditions, the effect of $\mathrm{T}_{3}$ that we describe can be obtained at concentrations of $T_{3}$ that are "physiological" or nearly so.

Studies carried out in our laboratories and those of our co-workers have defined a number of in vitro effects of $T_{3}$ that appear to have a strong commonality in respect to their major characteristics. These effects comprise the increase in 2-DG and 3-O-MG transport into rat thymocytes presently described, together with the previously demonstrated increases produced by $T_{3}$ in 2-DG accumulation by chick embryo cartilage and myocardial cells in culture (9-14). Two major characteristics of these effects are that they are very prompt in onset, being evident from $1 \mathrm{~min}$ or less to $30 \mathrm{~min}$ after addition of $\mathrm{T}_{3}$, and that they are not blocked by inhibitors of protein synthesis. These properties speak strongly against an action at a nuclear site. Rather, several lines of evidence lead us to suggest that they are mediated at the level of the cell membrane. First, they occur very promptly, as indicated above. Second, they appear to result from changes in functions in which the cell membrane is involved, i.e., inward transport of substrates or their rate of efflux from the cell. Finally, in the rat thymo- 
cyte, the enhancement of both amino acid ${ }^{4}$ and 2-DG accumulation that is produced by $\mathrm{T}_{3}$ is further increased by coincubation with beta adrenergic agonists, which themselves are thought to act at the level of the cell membrane. The likelihood that $\mathrm{T}_{3}$ acts directly on the cell membrane is strengthened by the recent demonstration in plasma membranes from rat hepatocytes of high affinity, low capacity binding sites for $\mathrm{T}_{3}$, whose affinity for other iodothyronines correlates well with their respective hormonal potency (55). The presence of such sites in the nucleus (1-5) and mitochondrion (8) has been taken to suggest that these are primary sites of $\mathrm{T}_{3}$ action. Nonetheless, it remains to be demonstrated that these sites are indeed linked to hormonal action at the membrane level, including the actions we have described.

\section{ACKNOWLEDGMENTS}

The authors are indebted to Dr. Bernard J. Ransil for advice concerning statistical analysis of the data. Data analysis was performed, in part, on the PROPHET System, a national computer resource sponsored by the Chemical/Biological Information Handling Program, National Institutes of Health.

This work was supported in part by research grant AM-18416 from the National Institute of Arthritis, Metabolism, and Digestive Diseases, and by grant RR-01032 from the General Clinical Research Centers Program of the Division of Research Resources, National Institutes of Health.

\section{REFERENCES}

1. Samuels, H. H., and J. S. Tsai. 1973. Thyroid hormone action in cell culture: demonstration of nuclear receptors in intact cells and isolated nuclei. Proc. Natl. Acad. Sci. U. S. A. 70: 3488-3492.

2. DeGroot, L. J., S. Refetoff, J. Strausser, and C. C. Barsano. 1974. Nuclear triiodothyronine-binding protein: partial characterization and binding to chromatin. Proc. Natl. Acad. Sci. U. S. A. 71: 4042-4046.

3. Oppenheimer, J. H., H. L. Schwartz, I. Koerner, and M. I. Surks. 1974. Limited binding capacity sites for Ltriiodothyronine in rat liver nuclei. Nuclear-cytoplasmic interrelation, binding constants, and cross-reactivity with L-thyroxine. J. Clin. Invest. 53: 768-777.

4. Spindler, B. J., K. M. McLeod, J. Ring, and J. D. Baxter. 1975. Thyroid hormone receptors. Binding characteristics and lack of hormonal dependency for nuclear localization. J. Biol. Chem. 250: 4113-4119.

5. Kistler, A., K. Yoshizato, and E. Frieden. 1975. Binding of thyroxine and triiodothyronine by nuclei of isolated tadpole liver cells. Endocrinology. 97: 1036-1042.

6. Hoch, E. L., and M. V. Motta. 1968. Reversal of early thyroid hormone action on mitochondria by bovine serum albumin in vitro. Proc. Natl. Acad. Sci. U. S. A. 59: 118-122.

7. Babior, B. M., S. Creagan, S. H. Ingbar, and R. S. Kipnes. 1973. Stimulation of mitochondrial adenosine diphosphate uptake by thyroid hormone. Proc. Natl. Acad. Sci. U. S. A. 70: $98-102$.

${ }^{4}$ Etzkorn, J., P. Hopkins, J. Gray, and S. H. Ingbar. Manuscript submitted for publication.
8. Sterling, K., P. O. Milch, M. A. Brenner, and J. H. Lazarus. 1977. Thyroid hormone action: the mitochondrial pathway. Science (Wash. D. C.). 197: 996-999.

9. Adamson, L. F., and S. H. Ingbar. 1967. Selective alteration by triiodothyronine of amino acid transport in embryonic bone. Endocrinology. 81: 1362-1371.

10. Adamson, L. F., and S. H. Ingbar. 1967. Some properties of the stimulatory effect of thyroid hormones on amino acid transport by embryonic chick bone. Endocrinology. 81: $1372-1378$.

11. Goldfine, I. D., G. J. Smith, C. G. Simons, S. H. Ingbar, and E. C. Jorgensen. 1976. Activities of thyroid hormones and related compounds in an in vitro thymocyte assay. J. Biol. Chem. 251: 4233-4238.

12. Goldfine, I. D., C. G. Simons, G. J. Smith, and S. H. Ingbar. 1975. Cycloleucine transport in isolated rat thymocytes: in vitro effects of triiodothyronine and thyroxine. Endocrinology. 96: 1030-1037.

13. Segal, J., H. Schwartz, and A. Gordon. 1977. The effect of triiodothyronine on 2-deoxy-D- $\left(1-{ }^{3} \mathrm{H}\right)$ glucose uptake in cultured chick embryo heart cells. Endocrinology. 101: 143-149.

14. Segal, J., and A. Gordon. 1977. The effect of actinomycin D, puromycin cyclohexamide and hydroxyurea on $3^{\prime}, 5,3-$ triiodo-L-thyronine stimulated 2-deoxy-D-glucose uptake in chick embryo heart cells in vitro. Endocrinology. 101: 150-156.

15. Somogyi, M. 1945. Determination of blood sugar. J. Biol. Chem. 160: 69-72.

16. Dunnett, C. W. 1970. Multiple comparison. In Statistics in Endocrinology. J. W. McArthur and T. Colton, editors. The M.I.T. Press, Cambridge, Mass. 79-103.

17. Kletzien, R. F., and J. F. Perdue. 1974. Sugar transport in chick embryo fibroblasts. I. A functional change in the plasma membrane associated with the rate of cell growth. J. Biol. Chem. 249: 3366-3374.

18. Kuroki, T., and S. Yamakawa. 1974. Effects of dibutyryl cyclic adenosine $3^{\prime}: 5^{\prime}$ monophosphate and theophylline on 2-deoxy-D-glucose and 2-aminoisobutyric acid uptake by hamster embryo cells. Int. J. Cancer. 14: 32-39.

19. Segal, J., and A. Gordon. 1977. The effect of 3,5,3'triiodo-L-thyronine on the kinetic parameters of sugar transport in cultured chick embryo heart cells. Endocrinology. 101: 1468-1474.

20. Kobayashi, M., and J. M. Olfesky. 1978. Long-term regulation of adipocyte glucose transport capacity by circulating insulin in rats. J. Clin. Invest. 62: 73-81.

21 Pittman, C. S., and J. A. Pittman. 1974. Relation of chemical structure to the action and metabolism of thyroactive substances. Hand. Physiol. 3(Sect. 7, Endocrinology): 232-253.

22. Kipnis, D. M., and C. F. Cori. 1959. Studies of tissue permeability. J. Biol. Chem. 234: 171-177.

23. Smith, D. E., and J. Gorski. 1968. Estrogen control of uterine glucose metabolism. An analysis based on the transport and phosphorylation of 2-deoxyglucose. J. Biol. Chem. 243: 4169-4174.

24. Scrutton, M. C., and M. F. Utter. 1968. The regulation of glycolysis and gluconeogenesis in animal tissues. Annu. Rev. Biochem. 37: 249-302.

25. Kletzien, R. F., and J. F. Perdue. 1974. Sugar transport in chick embryo fibroblasts. II. Alteration in transport following transformation by a temperature-sensitive mutant of the Rous sarcoma virus. J. Biol. Chem. 249: 3375-3382.

26. Guidotti, G., and P. P. Foa. 1961. Development of an insulin-sensitive glucose transport system in chick embryo hearts. Am. J. Physiol. 201: 869-872. 
27. Krahl, M. E. 1961. The Action of Insulin on Cells. Academic Press, Inc., New York.

28. Kalant, N., and R. Schucher. 1962. Glucose utilization and insulin responsiveness of leucocytes in diabetes. Can. J. Biochem. 40: 899-903.

29. Il'in, V. S., and L. A. Kil'dema. 1962. On the effect of cortisol and insulin on the activity of hexokinase in leukocytes. Vopr. Med. Khim. 8: 374-376.

30. Henderson, M. J. 1964. The uptake of glucose into cells and the role of insulin in glucose transport. Can. J. Biochem. 42: 933-944.

31. Crofford, O. B., and A. E. Renold. 1965. Glucose uptake by incubated rat epididymal adipose tissue. Rate limiting steps and site of insulin action. J. Biol. Chem. 240: $14-21$.

32. Crane, R. K. 1962. Hexokinases and pentokinases. In The Enzymes. P. D. Boyer, H. Lardy, and K. Myrback, editors. Academic Press, Inc., New York. 2nd edition. 6: $47-66$.

33. Weber, M. J. 1973. Hexose transport in normal and in Rous sarcoma virus-transformed cells. J. Biol. Chem. 248: 2978-2983.

34. Narahara, H. T., and P. Ozand. 1963. Studies of tissue permeability. IX. The effect of insulin on the penetration of 3-O-methyl glucose- $\mathrm{H}^{3}$ in frog muscle. J. Biol. Chem. 238: $40-49$.

35. Olefsky, J. M. 1975. Effect of dexamethasone on insulin binding, glucose transport and glucose oxidation of isolated rat adipocytes. J. Clin. Invest. 56: 1499-1508.

36. Vinten, J., J. Gliemann, and K. Osterlind. 1976. Exchange of 3-O-methyl glucose in isolated fat cells. Concentration dependence and effect of insulin. J. Biol. Chem. 251: 794-800.

37. Elrick, H., C. J. Hlad, Jr., and Y. Arai. 1961. Influence of thyroid function on carbohydrate metabolism and a new method for assessing response to insulin. J. Clin. Endocrinol. Metab. 21: 387-400.

38. Winnick, S. 1970. Response of hepatic glucokinase and glucose-6-phosphatase activities in juvenile and adult hyperthyroid mice. Endocrinology. 87: 124-128.

39. Burns, A. H., and W. J. Reddy. 1975. Diet effect of thyroid hormones on glucose oxidation by isolated rat cardiac myocytes. J. Mol. Cell. Cardiol. 7: 553-561.

40. Porterfield, S. P., and C. E. Hendrich. 1975. The effect of maternal hypothyroidism on maternal and fetal tissue glucose- $1-{ }^{14} \mathrm{C}$ incorporation in rats. Horm. Res. (Basel). 6: $236-246$.

41. Porterfield, S. P. 1977. The effects of maternal hyperthyroidism on the in vitro metabolism of $1{ }^{14} \mathrm{C}$-glucose in rats. Horm. Metab. Res. 9: 502-506.

42. Correze, C., J. Nunez, and A. Gordon. 1977. Thyroid hor- mones and lipogenesis from glucose in rat fat cells. Mol. Cell. Endocrinol. 9: 133-144.

43. Waldstein, S. S. 1966. Thyroid-catecholamine interrelations. Annu. Rev. Med. 17: 123-132.

44. Brodie, B. B., J. I. Davies, S. Hynie, G. Krishna, and B. Weiss. 1966. Interrelationships of catecholamines with other endocrine systems. Pharmacol. Rev. 18: 273-289.

45. Spaulding, S. W., and R. H. Noth. 1975. Thyroidcatecholamine interactions. Med. Clin. N. Am. 59: 11231131.

46. Landsberg, L. 1977. Catecholamines and the sympathoadrenal system. In The Year in Endocrinology, 19751976. S. H. Ingbar, editor. Plenum Publishing Corp., New York. 177-231.

47. Vaughn, M. 1967. An in vitro effect of triiodothyronine on rat adipose tissue. J. Clin. Invest. 46: 1482-1491.

48. Challoner, D. R., and D. O. Allen. 1970. An in vitro effect of triiodothyronine on lipolysis, cyclic AMP-C ${ }^{14}$ accumulation and oxygen consumption in isolated fat cells. Metab. Clin. Exp. 19: 480-487.

49. Ichikawa, A., H. Matsumoto, N. Sakato, and K. Tomita. 1971. Effect of thyroid hormones on epinephrine-induced lipolysis in adipose tissues of rats. J. Biochem. (Tokyo). 69: $1055-1064$.

50. Primack, M. P., J. L. Buchanan, and D. F. Tapley. 1970. Early stimulation of mitochondrial protein synthesis in livers from triiodothyronine-injected mice. Endocrinology. 87: 1355-1357.

51. Primack, M. P., D. F. Tapley, and J. Buchanan. 1971. Stimulation of mitochondrial protein synthesis and oxygen consumption by thyroxine in vitro without deiodination to triiodothyronine. Biochim. Biophys. Acta. 244: 349-352.

52. Buchanan, J., M. P. Primack, and D. F. Tapley. 1972. Equal stimulation in vivo of liver mitochondrial protein synthesis by thyroxine $\left(\mathrm{T}_{4}\right)$ and triodothyronine $\left(\mathrm{T}_{3}\right)$. Program of the Forty-Eighth Meeting of the American Thyroid Association, Inc., Chicago, Ill. 19. (Abstr.)

53. Yu, S., Y. Friedman, R. Richman, and G. Burke. 1976. Altered thyroidal responsivity to thyrotropin induced by circulating thyroid hormone. A "short loop" regulatory mechanism? J. Clin. Invest. 57: 745-755.

54. Friedman, Y., M. Lang, and G. Burke. 1977. Inhibition of thyroid adenylate cyclase by thyroid hormone: a possible locus for the "short loop" negative feedback phenomenon. Endocrinology. 101: 858-868.

55. Pliam, N. B., and I. D. Goldfine. 1977. High affinity thyroid hormone binding sites on purified rat liver plasma membranes. Biochem. Biophys. Res. Commun. 79: 166172. 